\title{
Signal Crosstalk Promoted Proliferative Lesions in Mouse Mammary Glands As a Consequence of ET-1 Overexpression
}

\author{
ET-1 Aşırı Anlatımının Bir Sonucu Olan, Sinyal Çapraz Etkileşimi 'Crosstalk', Fare \\ Meme Bezlerinde Proliferatif Lezyonların Oluşumunu Teşvik Eder
}

\author{
Nadir Gül' ${ }^{1}$, , Franz Theuring ${ }^{2}$ (두 \\ 'Faculty of Mathematics and Natural Sciences, Humboldt University of Berlin, Germany \\ ${ }^{2}$ Institute for Pharmacology, Charite University of Medicine Berlin, Germany
}

ORCID ID: N.G. 000000031259 4910; F.T. 0000-0003-1736-0312

Cite this article as: Gul N, Theuring F. Signal crosstalk promoted proliferative lesions in mouse mammary glands as a consequence of ET-1 overexpression. Experimed 2021;11(1): 1-11.

\begin{abstract}
Objective: As a distinct cellular signaling model, a receptor crosstalk between $G$ protein-coupled receptors (GPCR) and epiderma growth factor receptor (EGFR) has been demonstrated in various in vitro studies. In addition, recent in vitro studies had focused on the signaling pathways of endothelin-1 (ET-1) in the pathophysiology of cancer. Accordingly, a growing interest in the analysis of the receptor crosstalk between ET-1 receptors and EGFR and functional consequences of EGFR activation of proliferative diseases evoked us to the analysis of this phenomenon in vivo.
\end{abstract}

Materials and Methods: We performed a comparative study between ET-1 transgenic mice and control mice during the late pregnancy $(n=7)$, early lactation $(n=6)$ the mid of lactation $(n=10)$ and involution day $14(n=7)$ periods. Hematoxylin and eosin $(H E)$ stained parallel sections from mammary glands were microscopically examined. The key signal proteins (ETAR, ETBR, ERK1/2, pEG $F R$ ) in transactivation of EGFR were analyzed employing Western blot techniques. Genes (amphiregulin, TGFa, EGF, HB-EGF, ADAM 17) known to play an important role in these activities were analyzed using real-time PCR (RT-PCR) techniques.

Results: $E T-1$ transgenic mice exhibited hyperproliferative lesions (lactational hyperplasia) during the middle of the lactation period. Our RT-PCR analyses showed a prominent up regulation of amphiregulin and ADAM 17 in ET-1 transgenic mice. Moreover, we found higher EGFR and ERKs activations in the transgenic mammary glands. Conclusion: This study highlights a causative effect of upregulated $E T-1$ gene expression on the induction of proliferative lesions via EGFR transactivation in mammary glands. Further, ET-1 overexpression induced an upregulation of amphiregulin and ADAM17 expressions in the transgenic mammary glands. These results suggests that the enhanced ET-1 gene expression and its receptors might have a crucial role in proliferative diseases maintaining EGFR activation.

Keywords: Endothelin-1, EGFR transactivation, lactational hyperplasia, amphiregulin, transgenic mice

\section{öz}

Amac: Farklı bir hücresel sinyalleșme modeli olarak, G proteini ile eşleşmiş reseptörler (GPCR) ve epidermal growth faktör reseptör (EGFR) arasındaki reseptör çapraz etkileşimi (crosstalk), çeşitli in vitro çalışmalarda gösterilmiştir. Ayrıca, son dönem in vitro çalışmalar, endotelin-1 (ET-1) sinyal yolağının kanser patofizyolojisi üzerindeki ilişkisine odaklanmıştır. Bu bağlamda, ET-1 reseptörleri ve EGFR arasındaki reseptör çapraz etkileşim analizine ve EGFR aktivasyonunun fonksiyonel sonuçlarından proliferatif hastalıklara olan artan ilgi, bize bu fenomeni in vivo analiz etme fikrini oluşturmuştur.

Gereç ve Yöntem: ET-1 transgenik fareler ve kontrol fareleri arasında geç gebelik dönemi $(n=7)$, erken laktasyon dönemi $(n=6)$ orta dönem laktasyon $(n=10)$ ve involusyon 14. gün $(n=7)$ sırasında karşılaştırmalı bir çalışma gerçekleştirildi. Meme bezlerinden hematoksilen-eozin (HE) ile boyanmış paralel kesitler mikroskobik olarak incelendi. EGFR'nin transaktivasyonunda görev alan anahtar sinyal proteinleri (ETAR, ETBR, ERK1/2, pEGFR), Western blot teknikleri kullanılarak analiz edildi. Bu aktivitelerde önemli bir rol oynadığı bilinen genler (amfiregulin, TGFa, EGF, HB-EGF, ADAM 17), gercek zamanlı polimeraz zincir reaksiyonu (RT-PCR) teknikleri kullanılarak analiz edildi. Bulgular: ET-1 transgenik fareler, laktasyon döneminin ortasında hiper-proliferatif lezyonlar (laktasyonel hiperplazi) geliştirdi. RT-PCR analizlerimiz, transgenik farelerde amfiregulin ve ADAM 17 gen anlatımlarında belirgin bir artış olduğunu göstermektedir. Ayrıca transgenik meme bezlerinde daha yüksek EGFR ve ERKs aktivasyonları tespit edilmiştir.

Sonuç: Bu çalışma, yüksek seviyede ET-1 gen anlatımının EGFR yi transaktive etme yoluyla meme bezlerinde proliferatif lezyonları tetiklediğini göstermektedir. Ayrıca, ET-1 aşırı anlatımı, transgen meme bezlerinde amfiregulin ve ADAM17 anlatımlarının belirgin bir şekilde yukarı regülasyonuna neden olmaktadır. Bu sonuçlar bize ET-1 gen ekspresyonunu ve reseptörlerinin EGFR aktivasyonunu sağlayarak proliferatif hastalıklarda önemli bir role sahip olduğunu göstermektedir.

Anahtar Kelimeler: Endotelin-1, EGFR transaktivasyonu, laktasyonel hiperplazi, amfiregulin, transgenik fareler 


\section{INTRODUCTION}

Endothelin-1 (ET-1), an important substance in the maintenance of vascular tone, was firstly isolated and characterised by Yanagisawa from cultured supernatant of porcine aortic endothelial cells (6). ET-1 is expressed as an inactive precursor peptide comprising of 212 amino acid residues, named preproendothelin. Two endopeptidases control the activation process of preproendohelin (1). Firstly, the prepro form of endothelin is cleaved by a dibasic endopeptidase to form big ET-1 or proET-1 which is biologically inactive. Secondly, the conversion of proET-1 to the biologically active $E T-1$ is catalysed by a furin like protease named endothelin converting enzyme (ECE). The cleavage occurs in the intracellular compartments and on the cell surfaces and leads to the active ET-1. The active ET-1 comprises 21 amino acids and is folded by two disulphide bridges designating the half-life of the biological activity (2). The half-life of ET-1 in vivo is less than one minute whereas proET-1 lasts approx. 20-25 mins (3). Therefore, under normal physiological conditions ET-1 is not a circulating hormone but rather ET-1 functions in an autocrine or paracrine manner at multiple locations in the body $(4,5)$.

$E T-1$ exerts its effect by binding to two distinct $G$ protein-coupled receptors (GPCR), the endothelin A (ETAR) and endothelin $B$ receptor (ETBR). However, on the functional level both receptors differ, ETAR predominantly mediates vasoconstriction in vascular smooth muscle cells (6) whereas, ETBR activation results in vasodilatation in vascular endothelial cells (7).

In addition to typical GPCR signal characteristics, these receptors are also able to communicate with structurally unrelated receptors (transactivation) such as the epidermal growth factor receptor $(E G F R)$, the most prominent receptor tyrosine kinase, (8-10) resulting in EGFR characteristic intracellular signals (Figure 1). The EGFR mediated signaling pathway is positioned to affect duct formation as well as the outgrowth and branching of the mammary gland during pregnancy (11-13).

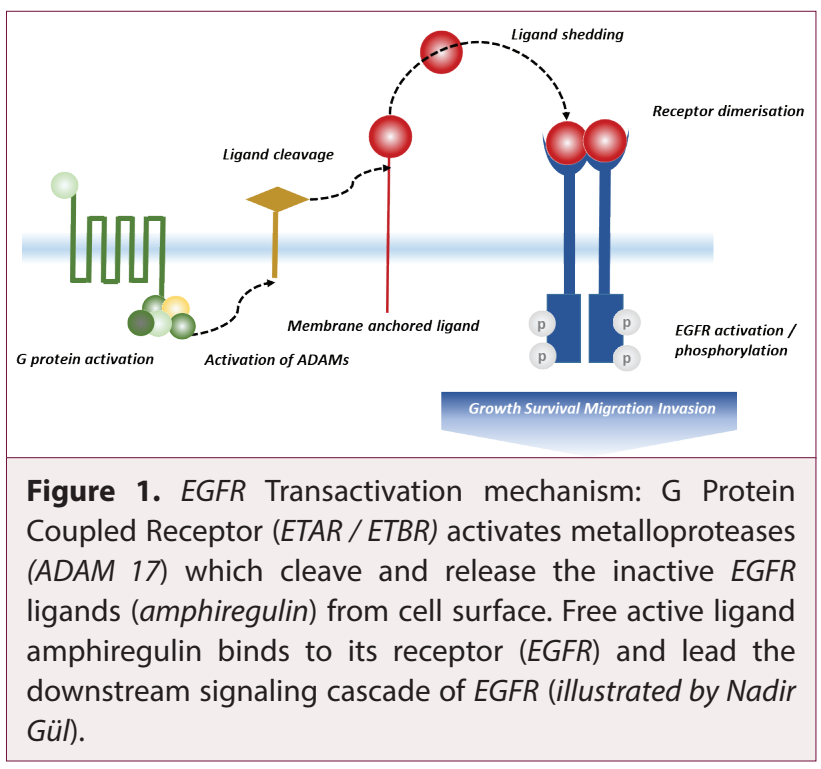

Further, recent studies reported that morphogenesis of the mammary gland requires paracrine activation of the EGFR via metalloprotease dependent shedding of amphiregulin $(14,15)$. Transactivation of the EGFR is regulated by various cellular responses such as overexpression, amplification or mutation of critical pathway elements with variable functional outcomes which are frequently linked to hyperproliferative diseases.

Indeed, GPCR induced EGFR transactivation was found to mediate cell proliferation in breast cancer cells $(16,17)$ and an increase of tumorigenicity in ovarian cancer cells (18). Activation of EGFR affects a wide range of cellular responses, depending on the coordinate expression of the cognate ligand (19). Up to now, eight EGF like ligands that directly activate the EGFR have been identified: EGF, TGFa, heparin binding-EGF (HB-EGF), amphiregulin, betacellulin, epiregulin, epigen and cripto (20-25). Each of these molecules activates receptors of the HER family of tyrosine kinase receptor by autocrine or paracrine stimulation (26). The upregulation of these ligands is believed to be critical for the tumor growth.

A number of studies point out receptor crosstalk under controlled experimental models such as cancer cell lines. The purpose of this study was to compare the results of the above-mentioned in vitro studies under in vivo and non neoplastic physiology. Therefore, we also systematically analyzed possible tumorigenic effect of $E T-1$ via receptor transactivation on ET-1 overexpressing mice model.

\section{MATERIALS AND METHODS}

\section{Mouse Models}

In this study the outbred strains NMRI (Harlan-Winkelmann, Paderborn) as wild type and NMRI originated homozygotic human ET-1 transgenic mice were used. These transgenic mice have been extensively characterized for their cardiovascular and renal phenotypes (27).

The animal experiments were maintained by dividing the groups of animals under three physiologic conditions; Pregnancy day $18(n=7)$, lactation day $3(n=6)$, lactation day 14 $(n=10)$ and involution day $14(n=7)$.

Mammary gland samples were obtained free of the muscles of the anterior abdominal wall and skin by blunt dissection on late pregnancy and lactation physiological stages. Animals had free access to standard mouse chow (mouse chow 5015) and tap water. The mice were routinely screened for common mouse pathogens.

The animals were sacrificed by cervical dislocation. In general, male and female mice were held separately in groups of 2-6 animals. All animal experiments were conducted in accordance with the German Law for animal protection (Tierschutzgesetz).

Histology, Immunohistochemistry; The mammary glands were fixed in paraformaldehyde for a minimum of 12 hours at room temperature. After the fixation process, the tissue sam- 
ples were embedded in paraffin blocks and cut in at $5 \mathrm{~mm}$ sections. The sections were submitted to hematoxylin-Eosin (HE) staining or incubated with SMA antibody. These slides were evaluated with blinded analytical protocol.

\section{Western Blots Analyses}

Frozen mammary gland samples were pulverized in LN2 with a mortar and a pestle. $100 \mathrm{mg}$ tissue samples were homogenized in urea lysis buffer. After the centrifugation, the supernatants were placed into new tubes. Protein concentration was measured with the Bradford colorimetric assay.

Samples $(25 \mu \mathrm{g})$ were run on SDS (12\%) polyacrylamide gels, blotted onto nitrocellulose membrane (Amersham) and incubated with blocking solution in TBS with $0.1 \%$ tween 20 for 1 hour at room temperature. Membranes were incubated with primary antibody diluted in blocking solution overnight at $4^{\circ} \mathrm{C}$ and detected using horseradish peroxidase conjugated secondary antibodies in conjunction with ECL (Amersham).

Immunoprecipitation; Grinded mammary gland samples were lysed in ice cold RIPA buffer. Lysates containing $400 \mu \mathrm{g}$ of proteins in RIPA buffer were incubated with $2 \mu \mathrm{g} / \mathrm{ml}$ EGFR antibody at $4^{\circ} \mathrm{C}$ overnight. The immune complex was precipitated with protein A sepharose $\mathrm{CL}-4 \mathrm{~B}$ beads at $4^{\circ} \mathrm{C}$ for $1 \mathrm{hr}$. The beads were washed ( 3 times) with PBS containing tween-20 (1\%) and spin down by centrifugation (2000 rpm for $1 \mathrm{~min}$ ), re-suspended in RIPA buffer and boiled for $5 \mathrm{~min}$ at $95^{\circ} \mathrm{C}$ in a thermomixer (Eppendorf). The samples were spin-down at $2000 \mathrm{rpm}$ for 1 $\min$. The supernatants were carefully placed in new tubes and immunoblotted with EGFR (pY845) and EGFR (Y1005), respectively (Table 1).

\section{Gene Expression Analyses}

Total RNA was extracted from quick-frozen mammary glands (50-100 mg per sample) using standard trizol extraction method (Invitrogen). RNA quantification was performed with a bio-analyzer (Agilent 2100) using a microfabricated chip (Agilent RNA 6000 Nano). The system was able to report not only the amount of RNA but also the $260 / 280 \mathrm{Nm}$ ratio and the RNA integrity number (RIN). RIN is a scale (from 1 to 10 ) to measure degradation and quality of RNA. Higher RIN value represents a better quality of RNA. Less than 9 RIN scaled samples were not used.

Prior to cDNA synthesis, all crude RNA samples were routinely treated with DNase1 (TurboDNase, Ambion). cDNA was synthetized from 1000 ng of total RNA using Promega MMLV reverse transcriptase enzyme with oligo(dT)18 Primers according to the manufacturer's protocol.

For the quantitative detection, the primers were designed using Ensembl gene data base and employing a commercial software (Primer 3) and web based algorithms (NCBI Blast, multi align) otherwise, the primer sets used from the literature were specified. All these primers were purchased from Invitrogen, Oligo (dT)18 were obtained from Promega (Table 2). The quantitative PCRs were performed using sybergreen mastermix (Applied Biosystems) and were carried out (25 ng template per test) in triplicate in MX 3700p Real-time PCR (RT-PCR) system (Stratogene).

\section{Statistical Analyses}

Western blots analyses; The digitized membranes were evaluated by special software (AlphaEaseFC) and the densitometric data were analyzed using a student's t-test by a statistical analysis program (Graphpad prism).

Gene Expression Analyses; Primer efficiency, standard curve and expression analyses were performed with the software Relative Expression Software Tool (REST 2008) which is using Pair Wise Fixed Reallocation Randomisation Test for statistical analyses (28).

\section{RESULTS}

ET-1 acts through its two G-protein coupled receptors, the ETAR and the ETBR. To determine whether overexpression of $E T-1$ in transgenic animals was accompanied by changes in the expression levels of these two receptors, expression of both re-

Table 1. The following antibodies were used in immunoprecipitation and Western blot analyses

\begin{tabular}{llll}
\hline Antibody & Origins and Dilutions & Molecular weight (kDa) & Reference \\
\hline pEGFR & Rabbit polyclonal antibody (tyr 845) & 170 & Cell signaling Tech. \\
\hline EGFR & Rabbit polyclonal antibody (tyr 1005) & 170 & Santa Cruz Biotech. \\
\hline ETAR & Rabbit polyclonal antibody & 69 & Cell signaling Tech. \\
\hline ETBR & Rabbit polyclonal antibody & $49 / 34$ & Cell signaling Tech. \\
\hline PERK & Rabbit polyclonal antibody & $42 / 44$ & Cell signaling Tech. \\
\hline ERK & Rabbit polyclonal antibody & $42 / 44$ & Cell signaling Tech. \\
\hline SMA & Mouse monoclonal antibody & -- & Sigma \\
\hline Antimouse Ig & Rabbit, HRP linked polyclonal antibody & - & Dakocytomation \\
\hline Antirabbit lg & Goat, HRP linked polyclonal antibody & & Dakocytomation \\
\hline
\end{tabular}


Table 2. The following primer sets were used in RT-PCR analysis.

\begin{tabular}{|c|c|c|}
\hline Gene & Forward Primers (5'-3') & Reverse Primers ( $\left.5^{\prime}-3^{\prime}\right)$ \\
\hline ADAM 17 (mouse) (56) & ACTCTGAGGACAGTTAACCAAACC & AGTAAAAGGAGCCAATACCACAAG \\
\hline Amphiregulin (mouse) & TCTTGGGCTTAATCACCTGTTC & GGGGACTACGACTACTCAGAG \\
\hline EGF (mouse) & CTAAGGATCCTGACCCCGAACT & GTACAGCCGTGATTCTGAGTGG \\
\hline EGFR (mouse) & GCCAATAATGTCTGCCACCT & TCCCAGTGGCAATAGATGGT \\
\hline ETAR (mouse) & GCTGGTTCCCTCTTCACTTAAGC & TCATGGTTGCCAGGTTAATGC \\
\hline ETBR (mouse) & TGTGCTCTAAGTATTGACAGATATCGAG & GGCTGTCTTGTAAAACTGCATGA \\
\hline HB-EGF (mouse) & TGAACCTTTTCAAAGTTGCTTTCT & CGTGGATGCAGTAGTCCTTGTA \\
\hline GAPDH (mouse) & CTTCACCACCATGGAGAAGGC & GGCATGGACTGTGGTCATGAG \\
\hline TGFa (mouse) & CAGAGGGCAGTACAGTTGATTCAG & GAAGACATCCTGGGCAAGC \\
\hline
\end{tabular}

ceptors in the mouse mammary glands of day 3 lactating wild type and transgenic ET-1 mice was determined at the mRNA and the protein level by RT-PCR and Western blotting, respectively. The mRNA expression of the ETAR and ETBR in ET-1 transgenic mice did not differ from wild type animals. Additionally, this result was confirmed at the protein level for the two receptors (Figure 2).

Throughout the second half of lactation, some parts of the mammary gland displayed intense lobular proliferation with cells characterized by increased cytoplasmic volume and enlarged nuclei (Figure 3 C, D) in the transgenic group.

Although no definite signs of pathological dysplasia were detected, alveolar organization was lost in parts of these areas. Therefore, immunohistostaining of smooth muscle actin was employed in order to rule out an underlying malignant transformation. HE and smooth muscle actin (SMA) immunohistostaining was performed on parallel sections obtained from wild type and ET-1 transgenic mammary glands. The slides were immunostained with an anti-SMA antibody and show brown colored myoepithelial cells enclosing the alveolar epithelial cells blue colored (Figure 3, F, H). The slides not treated with $S M A$ antibody were utilized as negative control, ensuring specifity of the SMA immunohistostaining (Figure $3 \mathrm{E}, \mathrm{G}$ ). SMA immunostaining clearly manifests the non-neoplastic structure by the presence of myoepithelial cells surrounding alveoli in the ET-1 transgenic mice.

EGFR activation has an important role in mammary ductal outgrowth and branching $(29,30)$. Deregulation of the activity of this receptor has a strong correlation with tumor progression

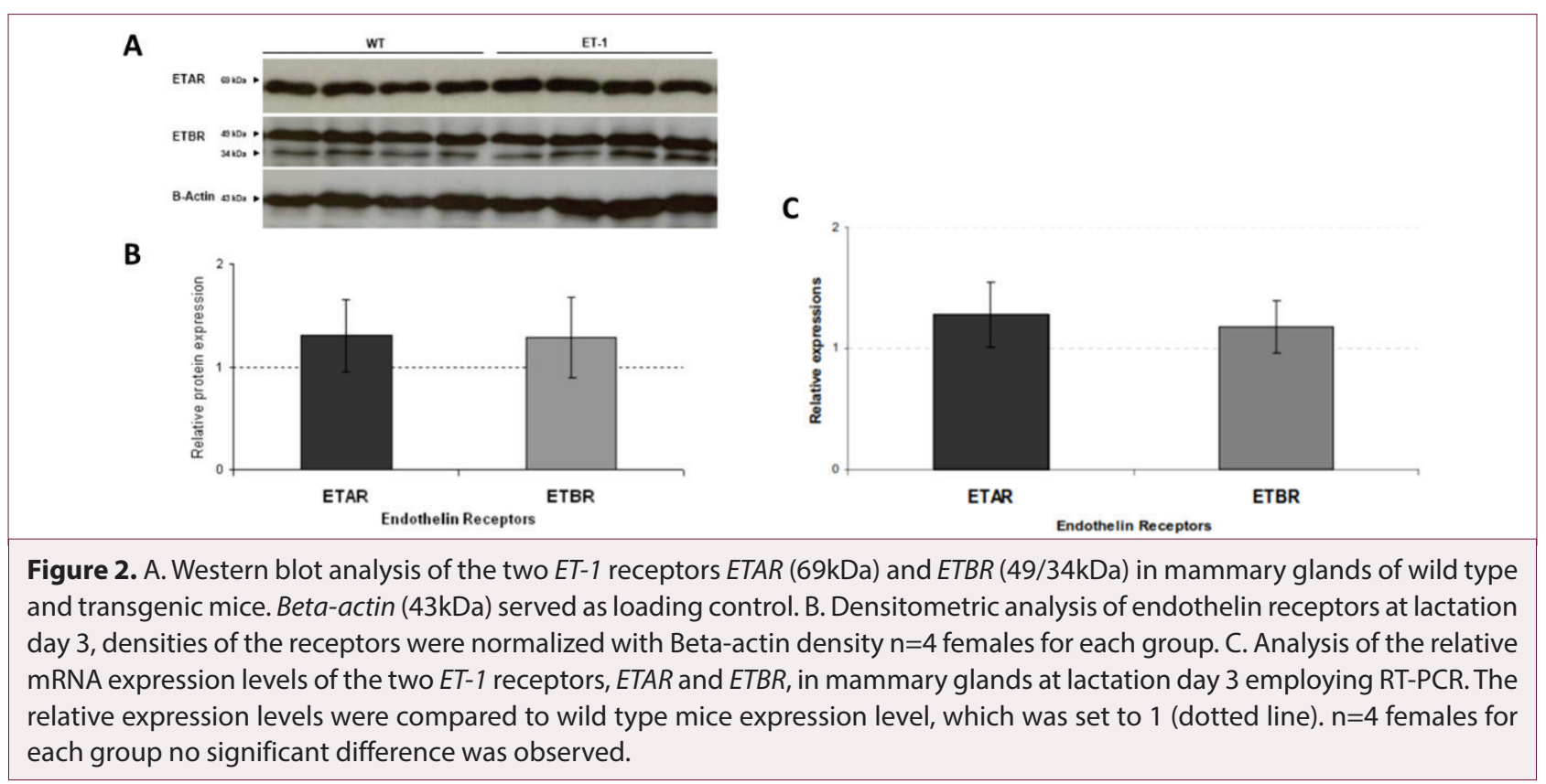




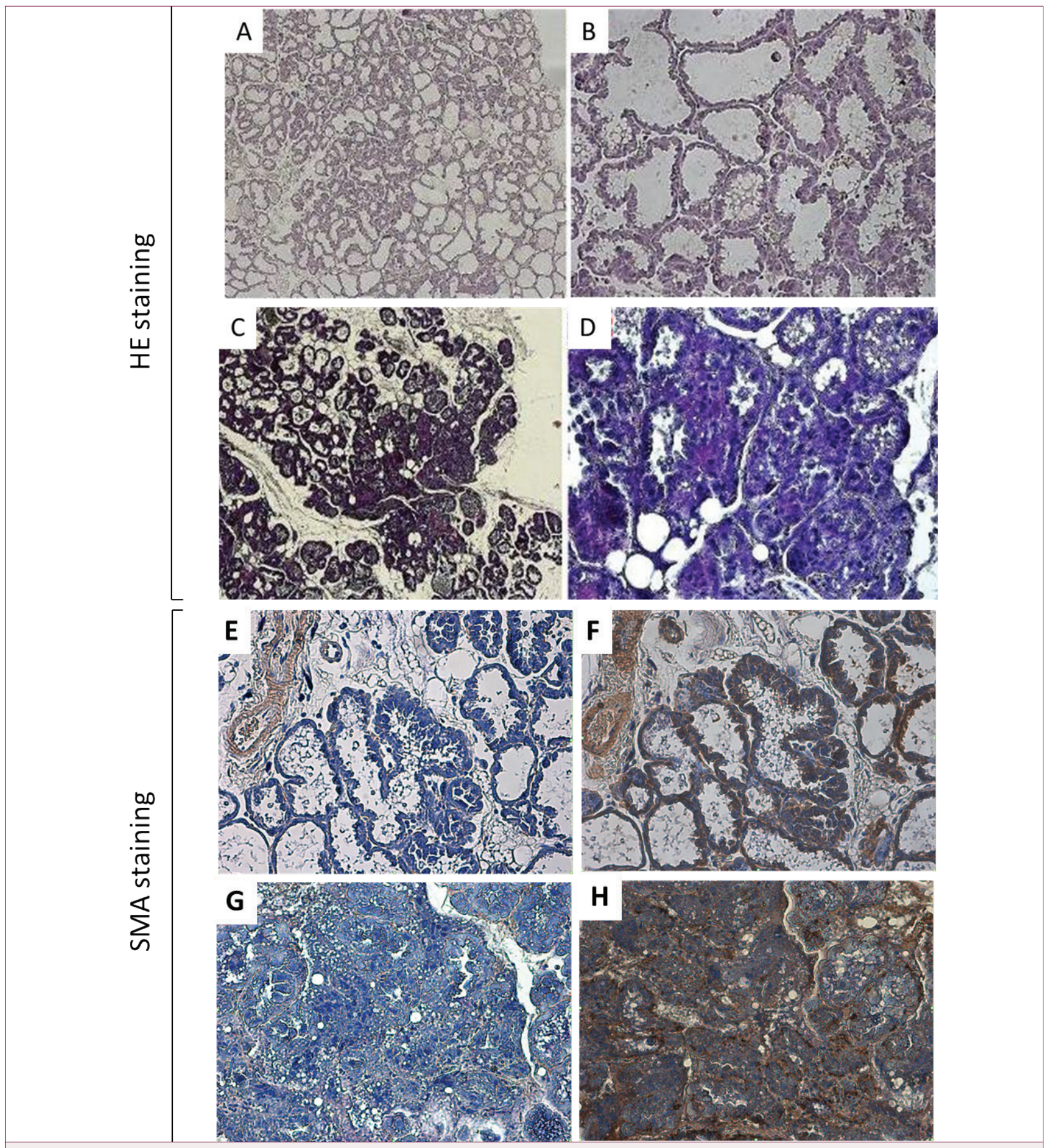

Figure 3. Histological features of the mammary gland at the lactation day 14. HE stained tissue sections; wild type: A; wild type: $B$; ET-1: C (x 50 magnification); ET-1: D (x 200 magnification). Wild type mammary glands exhibited fully expanded alveoli reflecting the highly active secretory capacity $(A, B)$. $E T-1$ transgenic mammary glands exhibited focal hyper proliferative lesions (C, D). SMA stained tissue sections; in order to visualize any possible cross reactivity for SMA staining parallel slides were treated without SMA antibody as negative control. Wild type: $\mathrm{E} ;$ ET-1: G (x 200 magnification), myoepithelium was stained by a SMA specific immunohistostaining method; brown colored areas in both groups indicated the SMA, wild type: F; ET-1: H (x 200 magnification), the wild type group demonstrated well organized alveoli and the individual alveoli are surrounded by blood vessels. On the other hand, the ET-1 group demonstrated hyper proliferative epithelium with SMA staining alveolar lumen and borders of alveoli become visual. 
(31). Lactational hyperplasia (Figure $3 \mathrm{G}, \mathrm{H}$ ) could be related to EGFR activation due to its central role on tumorigenesis. Therefore, EGFR phosphorylation was analyzed at lactation day 14 using immunoprecipitation techniques. As demonstrated in figures 5, an increased phosphorylation at residue $Y 845$ of the EGFR was observed in ET-1 transgenic mice compared to wild type. The phosphorylation at residue Y998 and Y1068 of the EGFR did not changed (data is not shown).

ERKs represent critical downstream molecules for ET-1 induced EGFR transactivation and might therefore be related to initiation of lactational hyperplasia. Hence, ERK activation was analyzed at pregnancy day 18 and lactation day 3 (Figure 4 C, D). The Western blot analysis represented that during pregnancy day 18 , as well as during lactation day 3, a pronounced activation of ERK 1 and ERK2 signaling could be detected in the mammary glands of $E T-1$ transgenic mice when compared to wild type mice (Figure 4E).

In order to identify ligands which are potentially involved in the observed activation of the EGFR, RT-PCR analyses were employed and the expression of EGF, TGFa, HB-EGF and amphiregulin was quantified at the transcript level.
As shown in figure $5 \mathrm{~A}$, expression analyses on the $14^{\text {th }}$ day of lactation demonstrated only a significant increase for the amphiregulin level in ET-1 transgenic compared to wild type mice, whereas the expression level of other ligands remained unchanged.

It is known that, amphiregulin expression was found to be increased during pregnancy but after parturition its transcription dramatically decreased due to its functional role on ductal development of the mammary gland $(32,33)$. Whether this significant upregulation of amphiregulin synthesis caused by high ET-1 expression, RNA levels of amphiregulin were analyzed at pregnancy day 18. As depicted in Figure $5 \mathrm{~B}$ amphiregulin is also significantly upregulated at pregnancy day 18 .

$A D A M 17$, the transmembrane metalloproteinase, is responsible for amphiregulin activation (54). Therefore, ADAM 17, as a key component of this signaling mechanism, was also analyzed employing RT-PCR techniques. As shown in figure 5C, ADAM 17 expression was significantly upregulated in $E T-1$ transgenic mice.

Following the lactation period, ET-1 transgenic mice were analysed with HE staining in order to find out the presence of

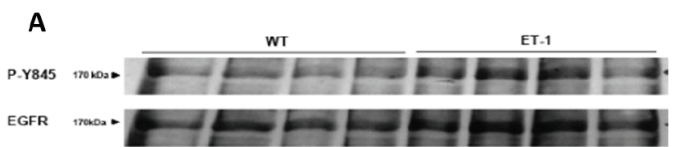

B

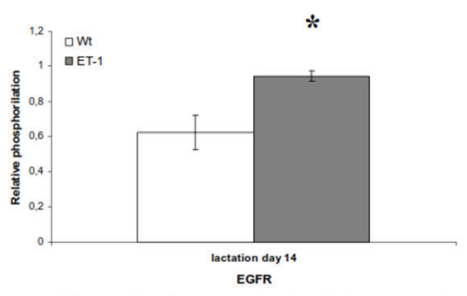

E

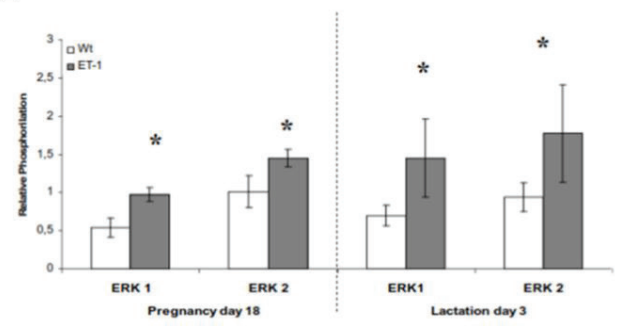

Figure 4. A. Analysis of the EGFR phosphorylation at lactation day 14 was determined by immunoprecipitation. $\sim 400 \mu g$ protein lysate for each sample has been used for immunoprecipitation with an EGFR specific antibody (with Y1005), activation of EGFR has been monitored by phosphor specific antibody $Y 845$ and EGFR served as loading control. B. The representative densitometric analysis of relative EGFR phosphorylation in wild type and ET-1 transgenic mice on the $14^{\text {th }}$ day of lactation. ET-1 transgenic mammary glands exhibited significantly more phosphorylated EGFR than the wild type counterparts C. At $18^{\text {th }}$ day of pregnancy, protein expression and phosphorylation of ERK $1(44 \mathrm{kDa})$ and ERK $2(42 \mathrm{kDa})$, proteins were determined by Western blotting. Betaactin served as control for loading. $25 \mu \mathrm{g}$ protein extract was loaded for each sample. D. 3 rd. day of lactation protein expression and phosphorylation of ERK $1(44 \mathrm{kDa})$ and ERK $2(42 \mathrm{kDa})$. E. The representative densitometric analysis of relative ERK 1 and ERK 2 phosphorylation ET-1 transgenic mammary glands exhibited significantly more phosphorylated ERK 1 and ERK 2 than the wild type counterparts ( $n=4$ mice for each group. $\left({ }^{*}\right) p<0.05$ Student's t-test). 


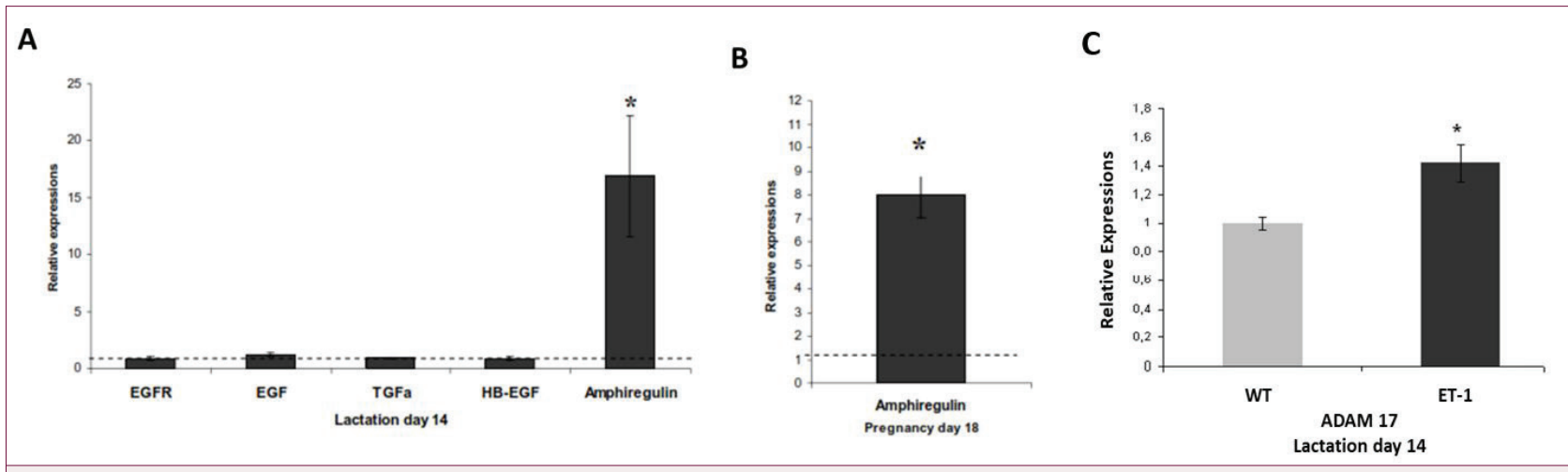

Figure 5. A. Relative expression of EGFR and its prominent ligands EGF, TGFa, HB-EGF, Amphiregulin at lactation day 14. B. Relative expression of amphiregulin at pregnancy day $18 \mathrm{C}$. Relative expression of ADAM17 at lactation day 14 . The relative expression levels were compared to wild type mice expression levels, which was set to 1 (dotted line). $\left({ }^{*}\right)$ : Pair Wise Fixed Reallocation Randomisation Test (28) $p<0.05 n=5$ mice for each group.
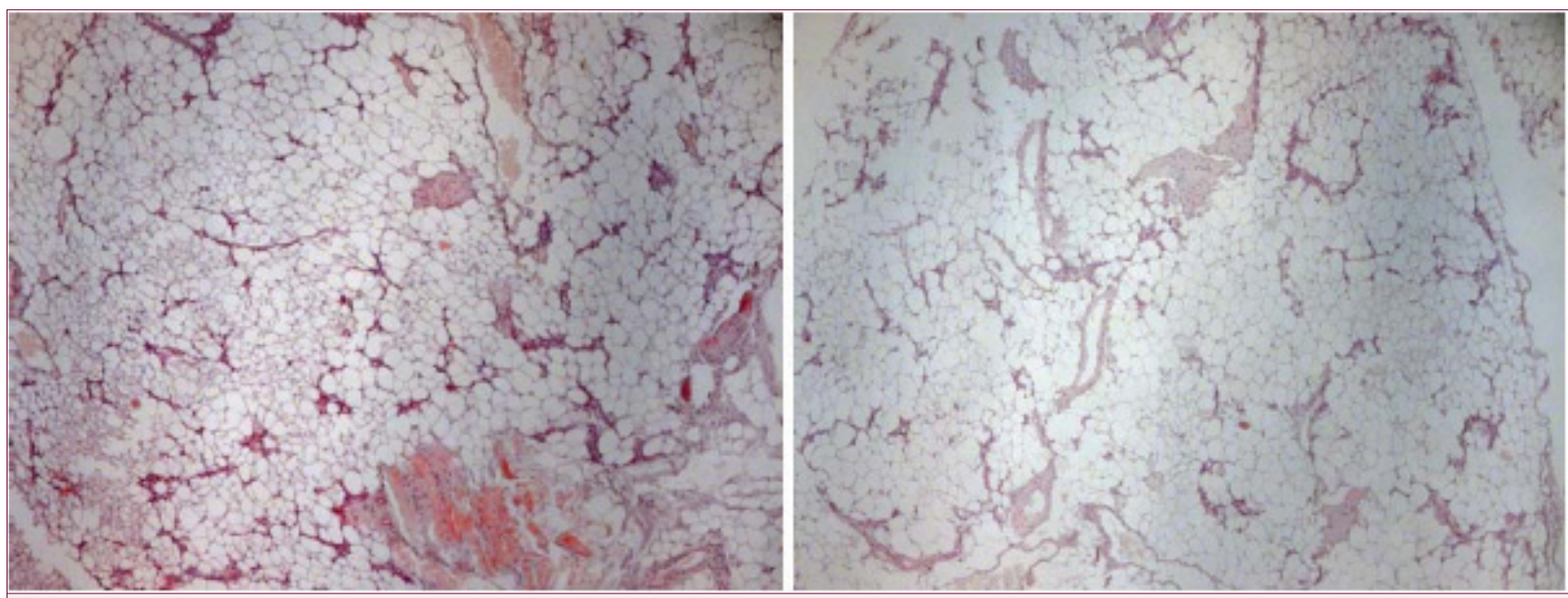

Figure 6. Histological features of the mammary gland at the $14^{\text {th }}$ day of involution. The tissue sections were stained with $\mathrm{HE}$ of wild type (left) and ET-1 transgenic mammary glands (right) (x 50 magnification). Both mammary glands showed same histological patterns of involution with the adipocytes and rudimentary epithelium. No hyperproliferative lesion or any type of irregularity was detected in both animal groups.

benign tumors at the involution day 14 stage. Throughout the involution no proliferative lesions were detected (Figure 6).

\section{DISCUSSION}

Along with its well-known effect on cardiovascular biology, $E T-1$ has also been associated with a wide range of biological activities including mitogenic and proliferative responses in vascular smooth muscle cells and other cell types (34). However, this proliferative aspect of ET-1 is not only involved in developmental progress. For instance, increased ET-1 expression has been demonstrated in a variety of solid tumors thereby promoting growth and inhibiting apoptosis in breast cancer while decreasing tumor cell differentiation (35-38). However, none of these reports described the causative effect of ET-1 on hyperproliferative lesions.
In this study, ET-1 transgenic mice displayed intense lobular proliferation in various grades in mammary glands during lactation. Further, alveolar organization was lost in parts of these areas (Figure 3). Suggesting the overexpression of ET-1 might contribute to mammary tumorigenicity.

One indication of a neoplastic progression is the loss of normal tissue architecture, including polarity. Generally, primary breast carcinomas show a dramatic increase in the ratio of luminal to myoepithelial cells, and many invasive breast carcinomas essentially lack myoepithelial cells completely (39). After the SMA immunohistostaining, these histological observations pointed to lactational hyperplasia in ET-1 transgenic mammary glands during the middle of the lactation period (Figure $3 \mathrm{G}, \mathrm{H}$ ). 
The lactational hyperplasia is known as a benign mammary lesion unique to pregnancy and lactation. This lesion may occur in response to the alteration of physiological conditions which represent pregnancy and lactation and it diminish spontaneously after the lactation $(40,41)$.

A possible causative effect of ET-1 overexpression on the development of lactational hyperplasia might have been mediated by the interaction of its GPCRs with the EGFRs, since ET-1 is known to possess growth regulatory properties $(3,8,42)$.

$E T-1$ exerts its effect by binding to two distinct GPCR, ETAR and $E T B R$. In addition to typical GPCR signal characteristics, these receptors are also able to communicate with structurally unrelated receptors such as the EGFR, the most prominent receptor tyrosine kinase $(8,9)$, resulting in EGFR characteristic intracellular signals. The expression level of both endothelin receptors was determined using RT-PCR and Western blotting (Figure 2) and no difference could be detected between wild type and transgenic animals, suggesting that the increase in expression of ET-1 is not influencing the expression of its receptors in this biological system.

Initial Western blot studies performed with mammary glands derived from ET-1 transgenic mice were not able to detect an EGFR signal during the lactation period. Therefore, immunoprecipitation was employed to detect total EGFR and phosphor-EGFR. Structurally, EGFR contains multi phosphorylation sites in intracellular domains, and several tyrosine $(Y)$ phosphorylation domains (Y845, Y998 and Y1068) were analyzed during initial studies on EGFR activation (data not shown). Figure $4 E T-1$ transgenic mice exhibits significantly more active $E G F R$ phosphorylation on the specific domain tyrosine 845 residue. It has been reported that various GPCR agonists including ET-1 could stimulate the phosphorylation of $Y 845$ in the EGFR in vitro (43).

Due to the technical difficulty to demonstrate the EGFR transactivation in vivo, we have analyzed also ERK protein activation which is the most well defined signalling pathway from the cell membrane to ERK 1 and ERK 2 is that mediated by the EGFR (44). ET-1 stimulates ERK 1 and ERK 2 through cognate GPCR receptors by transactivation of the EGFR in various cell types and tissues $(45,46)$. Additionally, increased ERK activation is documented in tubular hyperplasia as a result of $E T-1$ induction $(47,48)$. In Figure 4 C, D, E our Western blot studies represent that the transgenic group has significantly more active ERK1 and $E R K 2$ during pregnancy and lactation stages which implies us ET-1 induced EGFR transactivation in vivo.

To further characterize the assumed signaling network in ET-1 transgenic mammary glands, the most widely expressed ligands TGFa, EGF, HBEGF and amphiregulin, involved in the activation of the EGFR, were analyzed using RT-PCR. As presented in the Figure 5 the amphiregulin expression was significantly upregulated in ET-1 transgenic mice at lactation day 14 and pregnancy day 18 which is suggesting that the regulation of amphiregulin is influenced by the ET-1 overexpression. None of the three other ligands did exhibit significant differences in their expression level.

It was demonstrated that amphiregulin is a unique EGFR ligand for ductal branching and ductal outgrowth (49). Normally, amphiregulin expression is increased during pregnancy and decreased dramatically after parturition $(32,33)$. However, amphiregulin gene expression is upregulated in ET-1 transgenic mice both during pregnancy and lactation periods.

Moreover, it has been noted that high amphiregulin expression is strongly associated with breast carcinomas and neoplastic progression $(50,51)$. Several studies reported an increased amphiregulin expression in parallel to breast cancer. Therefore, amphiregulin was chosen as a pharmacological target for breast cancer treatment $(52,53)$.

$A D A M 17$, the transmembrane metalloproteinase, is responsible for amphiregulin activation. This is the upstream of EGFR dependent of signal pathway (54). ADAM 17 was analyzed employing RT-PCR techniques. As shown in Figure 5C, ADAM 17 expression was significantly upregulated in $E T-1$ transgenic mice during the lactation day 14.

The mechanism of ET-1 induced EGFR transactivation might provide a molecular explanation how overexpression of ET-1 could regulate the proliferative behaviour of tumor cells. Indeed, ET-1 transgenic mice were found with an increased EGFR activation in their mammary glands during lactation. Moreover, EGFR activation is maintained by an increased amphiregulin expression (55) which again might be regulated by the observed $E T-1$ overexpression.

Figure 6 represents mammary histology of both ET-1 transgenic and wild type mice mammary glands at involution day 14 . There was no residue of benign tumors found in ET-1 transgenic mice. Probably apoptotic process was stronger than cell survival. Therefore, those benign lesions were diminished due to the absence of ET-1 expression during the involution process. Since ET-1 expression does not take place within the involution we can not further elaborate tumorigenicity of ET-1in mammary gland physiology. However, the key components of signal transactivation (Figure 1) were found to be upregulated or more active while ET-1 expressions were higher than normal state. This result suggests the causative effect of ET-1 on pathophysiological alteration of the mammary glands taken place via EGFR transactivation.

Taken together, various studies underlining amphiregulin expressions and activation of EFGR, are positioned at the center of breast cancer or neoplastic transformation, as in this study, we focused on factors that might affect the regulation of this system. In this regard, the ET-1 axis reaches an important point in the understanding of cancer biology by increasing and therefore activating the characteristic genes observed in neoplastic transformation. Indeed, recent studies confirm our thoughts on the development of anticancer drugs to block endothelial receptors $(57,58)$. 
In future studies, by further studying the properties of the signal downstream of the ET-1 axis, we can find out more about the neoplastic transformation of the mammary glands on a larger scale.

Ethics Committee Approval: All animal experiments were carried out in accordance with German animal protection laws (Tierschutzgezetz), with the necessary permissions from Charite Universitatsmedizin Berlin.

Peer-review: Externally peer-reviewed.

Author Contributions: Concept - N.G., F.T.; Data Collection and/or Processing - N.G.; Analysis and/or Interpretation - N.G., F.T.; Literature Search - N.G., F.T.; Writing - N.G., F.T.

Conflict of Interest: The authors have no conflict of interest to declare.

Financial Disclosure: The authors declared that this study has received no financial support

Etik Komite Onayı: Bütün hayvan deneyleri Charite Tıp Fakültesi Berlin'de gerekli izinler alınarak Alman hayvan koruma kanunlarına (Tierschutzgezetz) uygun bir şekilde gerçekleştirilmiştir.

Hakem Değerlendirmesi: Dış bağımsız.

Yazar Katkıları: Çalışma Konsepti - N.G., F.T.; Veri Toplama N.G.; Veri Analizi/Yorumlama - N.G., F.T.; Yazma - N.G., F.T.

Çıkar Çatışması: Yazarlar çıkar çatışması bildirmemişlerdir.

Finansal Destek: Yazarlar bu çalışmada finansal destek almadıklarını beyan etmişlerdir.

\section{REFERENCES}

1. Itoh $\mathrm{Y}$, Kimura $\mathrm{C}$, Onda $\mathrm{H}$, Fujino $\mathrm{M}$. Canine endothelin-2: CDNA sequence for the mature peptide. Nucleic Acids Res 1989; 17(13): 5389. [CrossRef]

2. Takaoka M, Miyata Y, Takenobu Y, Ikegawa R, Matsumura Y, Morimoto $S$. Mode of cleavage of pig big endothelin-1 by chymotrypsin. Production and degradation of mature endothelin-1. Biochem J 1990; 270(2): 541-4. [CrossRef]

3. Battistini $B$, D'Orléans-Juste $P$, Sirois $P$. Endothelins: circulating plasma levels and presence in other biologic fluids. Lab Invest 1993; 68(6): 600-28.

4. Moraitis S, Miller WR, Smyth JF, Langdon SP. Paracrine regulation of ovarian cancer by endothelin Eur J Cancer 1999; 35(9): 1381-7. [CrossRef]

5. Marsault R, Feolde E, Frelin C. Receptor externalization determines sustained contractile responses to endothelin-1 in the rat aorta. Am J Physiol 1993; 264(3 Pt 1): C687-93. [CrossRef]
6. Yanagisawa M \& Masaki T. Endothelin, a novel endothelium-derived peptide. Pharmacological activities, regulation and possible roles in cardiovascular control. Biochem Pharmacol 1989; 38(12): 1877-83. [CrossRef]

7. Rozengurt E. Mitogenic signaling pathways induced by $G$ protein-coupled receptors. J Cell Physiol 2007; 213(3): 589-602. [CrossRef]

8. Cazaubon SM, Ramos-Morales F, Fischer S, Schweighoffer F, Strosberg AD, Couraud PO. Endothelin induces tyrosine phosphorylation and Grb2 association of Shc in astrocytes. J Biol Chem 1994; 269: 24805-9. [CrossRef]

9. Daaka Y. G proteins in cancer: the prostate cancer paradigm. Sci STKE 2004; re2. [CrossRef]

10. Wiesen JF, Young P, Werb Z, Cunha GR. Signaling through the stromal epidermal growth factor receptor is necessary for mammary ductal development. Development 1999; 126: 335-44.

11. Hynes NE \& Watson CJ. Mammary gland growth factors: roles in normal development and in cancer. Cold Spring Harb Perspect Biol 2010; 2(8): a003186. [CrossRef]

12. Daub H, Weiss FU, Wallasch $C$, Ullrich A. Role of transactivation of the EGF receptor in signalling by G-protein-coupled receptors. Nature. 1996; 379(6565): 557-60. [CrossRef]

13. Zhang Q, Thomas SM, Lui VW, Xi S, Siegfried JM, Fan $H$, et al. Phosphorylation of TNF-alpha converting enzyme by gastrin-releasing peptide induces amphiregulin release and EGF receptor activation Proc Natl Acad Sci U S A. 2006; 103(18): 6901-6.

14. Ciarloni L, Mallepell S, Brisken C. Amphiregulin is an essential mediator of estrogen receptor alpha function in mammary gland development. Proc Natl Acad Sci U S A. 2007; 104(13): 5455-60. [CrossRef]

15. Greco S, Muscella A, Elia MG, Salvatore P, Storelli C, Mazzotta A. Angiotensin II activates extracellular signal regulated kinases via protein kinase $\mathrm{C}$ and epidermal growth factor receptor in breast cancer cells. J Cell Physiol 2003; 196: 370-7. [CrossRef]

16. Muscella A, Greco S, Elia MG, Storelli C, Marsigliante S. PKC-z is required for angiotensin II-induced activation of ERK and synthesis of C-FOS in MCF-7 cells. J Cell Physiol 2003; 197: 61-8. [CrossRef]

17. Rosanò L, Di Castro V, Spinella F, Tortora G, Nicotra MR, Natali PG, et al. Combined targeting of endothelin $A$ receptor and epidermal growth factor receptor in ovarian cancer shows enhanced antitumor activity. Cancer Res 2007; 67(13): 6351-9. [CrossRef]

18. Peles $E \&$ Yarden $Y$. Neu and its ligands: from an oncogene to neural factors. Bioessays 1993; 15: 815-24. [CrossRef]

19. Cohen S. Nobel lecture. Epidermal growth factor Biosci Rep 1986; 6(12): 1017-28. [CrossRef]

20. Luetteke NC, Qiu TH, Fenton SE, Troyer KL, Riedel RF, Chang A, et al. Targeted inactivation of the EGF and amphiregulin genes reveals distinct roles for EGF receptor ligands in mouse mammary gland development. Development 1999; 126: 2739-50.

21. Higashiyama S, Lau K, Besner GE Abraham JA, Klagsbrun M. Structure of heparin-binding EGF-like growth factor. Multiple forms, primary structure, and glycosylation of the mature protein. J Biol Chem 1992; 267(9): 6205-12. [CrossRef]

22. Shoyab M, McDonald VL, Bradley JG, Todaro GJ. Amphiregulin: a bifunctional growth- modulating glycoprotein produced by the phorbol 12-myristate 13-acetate-treated human breast adenocarcinoma cell line MCF-7. Proc Natl Acad Sci U.S.A. 1988; 85(17): 6528-32. [CrossRef] 
23. Riese DJ, Komurasaki T, Plowman GD, Stern D. Activation of ErbB4 by the bifunctional epidermal growth factor family hormone epiregulin is regulated by ErbB2. J Biol Chem 1998; 273(18): 1128894. [CrossRef]

24. Strachan L, Murison JG, Prestidge RL, Sleeman MA, Watson JD, Kumble KD. Cloning and biological activity of epigen, a novel member of the epidermal growth factor superfamily. J Biol Chem 2001; 276(21): 18265-71. [CrossRef]

25. Salomon DS, Bianco C, De Santis M. Cripto: a novel epidermal growth factor (EGF)-related peptide in mammary gland development and neoplasia. Bioessays 1999; 21(1): 61-70. [CrossRef]

26. Troyer KL \& Lee DC. Regulation of mouse mammary gland development and tumorigenesis by the ERBB signaling network. J Mammary Gland Biol Neoplasia 2001; 6(1): 7-21.

27. Hocher B, Thöne-Reineke C, Rohmeiss P, Schmager F, Slowinski T, Burst $V$, et al. Endothelin-1 transgenic mice develop glomerulosclerosis, interstitial fibrosis, and renal cysts but not hypertension. J Clin Invest 1997; 99(6): 1380-9. [CrossRef]

28. Pfaffl MW, Horghan GW, Dempfle L. Relative expression software tool (REST) for group- wise comparison and statistical analysis of relative expression results in real-time PCR. Nucleic Acids Research 2002; 30(9): e36. [CrossRef]

29. Fowler, KJ, Walker F, Alexander W, Hibbs ML, Nice EC, Bohmer RM, et al. A mutation in the epidermal growth factor receptor in waved-2 mice has a profound effect on receptor biochemistry that results in impaired lactation. Proc Natl Acad Sci USA 1995; 92: 1465-9. [CrossRef]

30. Xie W, Paterson AJ, Chin E, Nabell LM, Kudlow JE. Targeted expression of a dominant negative epidermal growth factor receptor in the mammary gland of transgenic mice inhibits pubertal mammary duct development. Mol Endocrinol 1997; 11: 1766-81. [CrossRef]

31. Tsujioka H, Yotsumoto F, Shirota K, Horiuchi S, Yoshizato T, Kuroki $\mathrm{M}$, et al. Emerging strategies for ErbB ligand-based targeted therapy for cancer. Anticancer Res 2010; 30(8): 3107-12.

32. D'Cruz CM, Moody SE, Master SR, Hartman JL, Keiper EA, Imielinski MB, et al. Persistent parity-induced changes in growth factors, TGF-beta3, and differentiation in the rodent mammary gland. Mol Endocrinol 2002; 16(9): 2034-51. [CrossRef]

33. Schroeder JA \& Lee DC. Dynamic expression and activation of ERBB receptors in the developing mouse mammary gland. Cell Growth Differ 1998; 9: 451-64.

34. Bagnato A, Tecce R, Di Castro V, Catt KJ. Activation of mitogenic signaling by endothelin 1 in ovarian carcinoma cells. Cancer Res 1997; 57(7): 1306-11.

35. Alanen K, Deng DX, Chakrabarti S. Augmented expression of endothelin-1, endothelin-3 And the endothelin-B receptor in breast carcinoma. Histopathology 2000; 36(2): 161-7. [CrossRef]

36. Bagnato A, Rosano L, Di Castro V, Albini A, Salani D, Varmi M, et al. Endothelin receptor blockade inhibits proliferation of Kaposi's sarcoma cells. Am J Pathol 2001; 158(3): 841-7. [CrossRef]

37. Nelson J, Bagnato A, Battistini B, Nisen P. The endothelin axis: emerging role in cancer. Nat Rev Cancer 2003; 3(2): 110-6. [CrossRef]

38. Hagemann T, Binder C, Binder L, Pukrop T, Trumper L, Grimshaw, MJ. Expression of endothelins and their receptors promotes an invasive Phenotype of breast tumor cells but is insufficient to induce invasion in benign cells. DNA Cell Biol 2005; 24(11): 766-76. [CrossRef]
39. Gusterson BA, Ross DT, Heath VJ, Stein T. Basal cytokeratins and their relationship to the cellular origin and functional classification of breast cancer. Breast Cancer Res 2005; 7(4): 1438. [CrossRef]

40. Sabate JM, Clotet M, Torrubia S, Gomez A, Guerrero R, de las Heras $P$, et al. Radiologic evaluation of breast disorders related to pregnancy and lactation Radiographics 2007; 27(Suppl 1): S101-24. [CrossRef]

41. Shin SJ, Rosen PP. Carcinoma arising from pre-existing pregnancy-like and cystic hypersecretory lesions of the breast: a clinicopathologic study of 9 patients. Am J Surg Pathol 2004; 28: 789-93. [CrossRef]

42. Amee J. George Ross D. Hannan Walter G. Thomas Unravelling the molecular complexity of GPCR-mediated EGFR transactivation using functional genomics approaches. The FEBS Journal 2013; 280(21): 5258-68. [CrossRef]

43. Boerner JL, Biscardi JS, Silva CM, Parsons SJ. Transactivating agonists of the EGF receptor require Tyr 845 phosphorylation for induction of DNA synthesis. Mol Carcinog 2005; 44(4): 262-73. [CrossRef]

44. Joslin EJ, Opresko LK, Wells A, Wiley HS, Lauffenburger DA. EGF-receptor-mediated mammary epithelial cell migration is driven by sustained ERK signaling from autocrine stimulation. J Cell Sci 2007; 120(Pt 20): 3688-99. [CrossRef]

45. Cramer $\mathrm{H}$, Schmenger $\mathrm{K}$, Heinrich $\mathrm{K}$, Horstmeyer A, Böning $\mathrm{H}$, Breit $A$, et al. Coupling of endothelin receptors to the ERK/MAP kinase pathway. Roles of palmitoylation and G(alpha)q. Eur J Biochem 2001; 268(20): 5449-59. [CrossRef]

46. Hua $\mathrm{H}$, Munk $\mathrm{S}$, Whiteside $\mathrm{Cl}$. Endothelin-1 activates mesangial cell ERK1/2 via EGF- receptor transactivation and caveolin-1 interaction Am J Physiol Renal Physiol 2003; 284(2): F303-12. [CrossRef]

47. Kodama H, Fukuda K, Takahashi T, Sano M, Kato T, Tahara S, et al. Role of EGF Receptor and Pyk2 in endothelin-1-induced ERK activation in rat cardiomyocytes. J Mol Cell Cardiol 2002; 34(2): 13950. [CrossRef]

48. Chu TS, Wu MS, Wu KD, Hsieh BS. Endothelin-1 activates MAPKs and modulates cell cycle proteins in OKP cells. J Formos Med Assoc 2007; 106(4): 273-80. [CrossRef]

49. Jackson LF, Qiu TH, Sunnarborg SW, Chang A, Zhang C, Patterson $C$, et al. Defective valvulogenesis in HB-EGF and TACE-null mice is associated with aberrant BMP signaling. EMBO J 2003; 22(11): 2704-16. [CrossRef]

50. Sternlicht M \& Sunnarborg SW. The ADAM17-amphiregulin-EGFR axis in mammary development and cancer. J Mammary Gland Biol Neoplasia 2008; 13(2): 181-94. [CrossRef]

51. Gilmore JL, Scott JA, Bouizar Z, Robling A, Pitfield SE, Riese DJ, et al. Amphiregulin EGFR Signaling regulates PTHrP gene Expression in Breast cancer cells. Breast Cancer Res Treat 2008; 10(3): 493-505. [CrossRef]

52. Normanno N, Kim N, Wen D, Smith K, Harris AL, Plowman G, et al. Expression of messenger RNA for amphiregulin, heregulin, and cripto-1, three new members of the epidermal growth factor family, in human breast carcinomas. Breast Cancer Res Treat 1995; 35(3): 293-7. [CrossRef]

53. Willmarth NE \& Ethier SP. Amphiregulin as a novel target for breast cancer therapy. J Mammary Gland Biol Neoplasia 2008; 13(2): 1719. [CrossRef]

54. Mark DS, Susan WS. The ADAM 17 Amphiregulin EGFR axis in mammary development and Cancer. J Mammary Gland Biol Neoplasia 2008; 13: 181-94. [CrossRef] 
55. Gschwind A, Hart S, Fischer OM, Ullrich A. TACE cleavage of proamphiregulin regulates GPCR-induced proliferation and motility of cancer cells. EMBO J 2003; 22(10): 2411-21. [CrossRef]

56. Zheng $X$, Jiang F, Katakowski M, Zhang ZG, Lu QE, Chopp M. ADAM17 promotes breast cancer cell malignant phenotype through EGFR-PI3K-AKT activation. Cancer Biol Ther 2009; 8(11): 1045-54. [CrossRef]
57. L. Kappes, RL. Amer, S Sommerlatte, G Bashir, C Plattfaut, F Gieseler, et al. Ambrisentan, an endothelin receptor type A-selective antagonist, inhibits cancer cell migration, invasion, and metastasis. Nature Scientific Reports 2020; 10: 15931. [CrossRef]

58. HM Ahn, DG Kim, YJ Kim. Blockade of endothelin receptor A enhances the therapeutic efficacy of gemcitabine in pancreatic cancer cells. Biochem Biophys Res Commun 2020; 527(2): 568-73. [CrossRef] 